\title{
Parent's Perceptions and Concerns About Inhaled Asthma Therapy
}

\section{Perceções e Receios dos Pais Acerca da Terapêutica Inalatória na Asma}

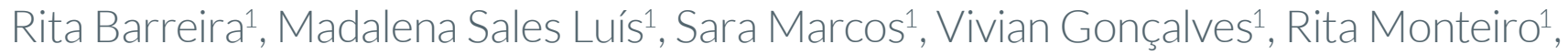
Maria João Leiria ${ }^{1}$

\begin{abstract}
AIM: To determine parent's perceptions and concerns about inhaled therapy and their relation to disease control. METHODS: A questionnaire was applied by interviewing parents of 119 asthmatic children attending the Pediatric Allergy or Pneumology outpatient clinic.

RESULTS: Eighty-one (68\%) parents expressed concerns and worries about the use of inhaled therapy in their children, either with controlled or partially/uncontrolled asthma ( $65 \%$ vs $78 \% p=0.22$ ). Regarding their beliefs about inhaled therapy, $11 \%(n=13)$ stated that they considered pMDI's/DPI's less effective than nebulizers. When questioned about the knowledge of their child's acute exacerbation therapy, $91.5 \%$ ( $n=109)$ reported knowing it, albeit only 40\% ( $n=44)$ did answer it correctly. Nine parents said they were unaware of their children's reliever treatment. DISCUSSION: We expected to find parental concerns about inhaled therapy, but such a high percentage wasn't expected. A substantial number of parents believe that their children can become addicted or dependent on the use of the inhaler. This finding reinforces the misconceptions parents do have regarding inhaled therapy. There is a higher proportion of parents with concerns in the group with partially/uncontrolled asthma, although it was not statistically significant. The majority of patients/parents reported knowing the reliever plan in an exacerbation, although most of them could not explain the plan correctly. These results are worrying, as they show parents have an inappropriate knowledge of reliever measures. Therefore, we suggest that improvements in education about inhaled therapy should be made, including the regular review of the inhalation technique and the reliever plan in every consultation. KEYWORDS: Administration, Inhalation; Anti-Asthmatic Agents; Asthma/drug therapy; Child; Parents
\end{abstract}




\section{RESUMO}

OBJETIVO: Avaliar os conhecimentos e receios dos pais relativamente à terapêutica inalada na asma e a sua relação com o controlo da doença.

MÉTODOS: Foi aplicado um questionário a 119 pais de crianças e adolescentes asmáticos, seguidos na Consulta de Alergologia ou Pneumologia pediátricas.

RESULTADOS: Oitenta e um pais (68\%) referiram receios relativamente ao uso de terapêutica inalada, quer no grupo com asma controlada quer com parcialmente/ não controlada ( $65 \%$ vs $78 \% p=0,22)$. Quanto às suas crenças sobre a medicação inalatória, 11\% ( $n=13$ ) considerou que os inaladores de pó seco/ inalador pressurizado doseável (DPI's/pMDl's) eram menos eficazes que os nebulizadores. Quando questionados sobre o seu conhecimento acerca da terapêutica de crise, 91,5\% $(n=109)$ respondeu conhecer o esquema, mas apenas $40 \%(n=44)$ soube explicá-lo corretamente. Nove pais afirmaram desconhecer a terapêutica de crise de asma dos seus filhos.

DISCUSSÃO: Era expectável encontrar medos relacionados com o uso da terapêutica inalada na asma, contudo não esperávamos uma percentagem tão elevada. Um número substancial de pais acredita que a terapêutica inalada causa habituação e dependência, o que reforça a existência de crenças erradas relativamente à terapêutica inalada com estes dispositivos. A proporção de pais com receios é maior na amostra de doentes com asma parcialmente e não controlada embora sem significado estatístico. A maioria dos pais respondeu que conhecia o esquema de crise, contudo a maioria não o soube explicar corretamente. Estes resultados são preocupantes mostrando um conhecimento inadequado dos pais face à abordagem da crise de asma. Nesse sentido, sugerimos uma melhoria da educação acerca da terapêutica inalada, incluindo a revisão regular da técnica inalatória e do plano de crise em todas as consultas.

PALAVRAS-CHAVE: Administração por Inalação; Asma/tratamento; Antiasmáticos; Criança; Pais

\section{INTRODUCTION}

Despite advances in medical management, childhood asthma continues to be a major cause of emergency department visits, hospitalizations, and missed school days. $^{1-3}$

According to the International Study of Asthma and Allergies in Childhood (ISAAC), there are $12.9 \%$ of children (6-7 years) and $11.8 \%$ of adolescents (13-14 years) with active asthma in Portugal. ${ }^{4}$

Inhaled therapy is currently the keystone in the management of pediatric asthma; it allows high levels of drug concentration in the airways, a more rapid onset of action and fewer systemic adverse effects compared to systemic drugs. ${ }^{5}$ There are two main types of inhaler devices available: pressurized metered dose inhalers (pMDl's) with a spacer system and dry powder inhalers (DPI's). Nebulizers are reserved for a minority of children who cannot be taught effectively how to use a spacer device. ${ }^{6}$ The use of an inhaler device is a skill that must be learned and maintained in order to the medication be applied effectively. One of the strategies to support effective self-management includes education of inhaled therapy and the regular assessment of the pa- tient's and family members' knowledge and capacity for self-management, including medication administration and inhaler technique. ${ }^{6}$ The 2018 Gina Report suggests that to ensure an effective use of inhalation devices, the inhaler technique should be checked at every opportunity because after initial training, mistakes often recur within the next 4 to 6 weeks. In addition to difficulties in using the inhaler, other factors may contribute to poor adherence, namely parent's concerns about side effects and its cost. ${ }^{7}$ Compliance is a major problem in any chronic disorder and parents who become apprehensive or may experience difficulties with inhaled therapy are less likely to enforce adhesion to treatment in their children. ${ }^{7}$ Parents and patient education and counseling are the main issues in ensuring successful adherence to a treatment regimen. Obtaining optimal asthma control is the primary goal of asthma management and a better understanding of determinants that influence asthma control can help optimize treatment.

Our aim was to determine the parent's perceptions and concerns about inhaled therapy and their relation to disease control. Secondarily we evaluated the importance parents give to teaching inhalation technique and their knowledge about reliever treatment. 


\section{METHODS}

\section{STUDY DESIGN}

This study was carried out at São Francisco Xavier Hospital, a level II hospital, in Lisbon. We prospectively included a convenience sample of parents of children and adolescents up to the age of 18 years with asthma, who attended the Pediatric Allergy and Pneumology outpatient clinic, between March and June 2018. All patients had been prescribed inhalation therapy (pMDI's or DPI's) in the form of bronchodilators and/or steroids. In the first appointment, we provide instructions about reliever therapy including the name of the medication, dose, and circumstances in which to take the medication. Education about inhalatory technique was provided by nurses and through educational leaflets available at the clinic, whenever a different device was prescribed.

\section{DATA COLLECTION}

Data collection was performed at the Pediatric Allergy and Pneumology outpatient clinic by four investigators, two from the Allergy Clinic and the other two from the Pneumology Clinic.

Parents were invited to participate in the research project at the end of each medical consultation and informed verbal consent was obtained. They were asked to fill out a questionnaire comprising 15 questions (Annex 1), which took approximately 5 minutes to complete. Before parents submitted the surveys, each investigator included in the questionnaire header the classification of asthma control - controlled asthma, partially controlled asthma and uncontrolled asthma.

TABLE 1. Patients studied $(n=119)$.

\begin{tabular}{lc} 
Mean age of patients (years \pm SD) & $11.2 \pm 4.8$ \\
\hline Sex ratio (male/female) & $72 / 47$ \\
\hline Patient's asthma control & $\mathrm{n}(\%)$ \\
\hline Controlled & $92(77.3)$ \\
\hline Partially controlled & $23(19.3)$ \\
\hline Uncontrolled & $4(3.4)$ \\
\hline Maintenance treatment & $\mathrm{n}(\%)$ \\
\hline ICS & $56(47.1)$ \\
\hline Combination ICS/LABA & $26(21.8)$ \\
\hline No treatment & $37(31.1)$ \\
\hline Period prescribed inhaler therapy & $\mathrm{n}(\%)$ \\
\hline$<3$ months & $3(2.5)$ \\
\hline $3-6$ months & $12(10.1)$ \\
\hline 7 months to 12 months & $12(10.1)$ \\
\hline$>12$ months & $90(75.6)$ \\
\hline NA & $2(1.7)$ \\
\hline
\end{tabular}

ICS - inhaled steroids; LABA - long-action beta2-agonist; NA - not available; $\mathrm{SD}$ - standard deviation
We recorded demographic data, as well as information about asthma family history, duration of inhaled therapy and the regularity they considered important to review inhalation technique. Parents were also asked about concerns they might have regarding inhaled therapy. To evaluate parent's beliefs concerning inhaled therapy, they were asked to compare the effectiveness of pMDI's/DPI's in relation to nebulizers. In the last question, about reliever therapy, parents were asked if they knew it, and if so to state the drug's name, dosage and to explain how they use it.

\section{DEFINITION OF VARIABLES}

Asthma control can be classified in various ways. Our study was based on the definition from the Global Initiative for Asthma. These guidelines state that good asthma control consists of no more than twice/week daytime asthma symptoms, absence of night-time awakenings due to asthma, no more than twice/week use of reliever treatment (excludes reliever taken before exercise) and no activity limitation due to asthma in the past four weeks. Patients with one or two of these items have partially controlled and with three or four have uncontrolled asthma. ${ }^{6}$

\section{DATA MANAGEMENT AND STATISTICAL ANALYSIS}

Data from the questionnaires was entered into an online database by two researchers (MSL, RB) and descriptive statistics was performed using Microsoft Exce ${ }^{\circledR}$. Data normally distributed is presented as mean \pm standard deviation (SD). Chi-square test was used for statistical comparison for categorical variables. A $p$-value less than 0.05 was considered significant.

\section{RESULTS}

A total of 119 parent-child/adolescent pairs were included in the study. The mean age was $11.2 \pm 4.8$ years with 72 boys and 47 girls. Baseline demographic characteristics of the patients enrolled are presented in Table 1. Of all the patients, $77.3 \%(n=92)$ had controlled asthma, 19.3\% ( $n=23$ ) partially controlled and four (3.4\%) had uncontrolled asthma. Regarding maintenance therapy, 56 patients were receiving inhaled steroids (ICS) and 26 a combination of ICS and long-acting beta -agonist $_{2}$ (LABA). In relation to family background, 78 patients had a family history of asthma. Baseline demographic characteristics of the parents enrolled are presented in Table 2.

When asked about teaching inhalation technique, 31\% $(n=37)$ of parents considered that it should be revie- 
wed at all consultations, 37\% ( $n=44)$ once a year and $32 \%(n=38)$ only once.

Eighty-one (68\%) respondents expressed concerns and worries regarding the use of inhaled therapy in their children, either with controlled or partially/uncontrolled asthma (65\% vs 78\% $p=0.22)$. The most common concerns were those associated with the side effects of the medication ( $n=60$ ) and an eventual dependence or addiction to it $(n=28)$. Fifteen parents considered inhaled therapy too costly and two felt that it was too difficult to administer (Fig. 1).

Regarding their beliefs about inhaled therapy, 61\% ( $n=73$ ) stated that they considered pMDI's/DPI's more effective than nebulizers, $25 \%(n=30)$ equally effective, $11 \%$ ( $n=13$ ) less effective and 3 did not respond. Awareness of the superior efficacy of nebulizers was reported by $12 \%$ and $24 \%$ ( $p=0.20$ ) of parents in the controlled asthma group versus uncontrolled/partially controlled asthma, respectively.

Regarding reviewing the reliever treatment frequency, $60 \%$ ( $n=71$ ) stated that revision was necessary in all clinics. When questioned about the knowledge of their child's acute exacerbation therapy, 91.5\% ( $n=109)$ reported knowing it, albeit only 40\% ( $n=44)$ did answer it correctly. Nine parents said they were unaware of their children's reliever treatment and one did not answer.

\section{DISCUSSION}

In our study uncontrolled or partially controlled asthma was present in approximately one-quarter (23\%) of the studied population.

Only about a third of parents (31\%) considered impor-

TABLE 2. Demographic data concerning parents.

\begin{tabular}{l|c|}
$\begin{array}{l}\text { Mean age of patients (years } \pm \text { SD) } \\
\text { Father }\end{array}$ & $43.5 \pm 7.7$ \\
Mother & $41.4 \pm 6.7$ \\
\hline Education of parents & $\mathrm{n}(\%)$ \\
\hline Father ( $\mathrm{n}=119)$ & $82(68.9)$ \\
\hline Primary/Secondary & $30(25.2)$ \\
\hline Diploma/degree-holders & $7(5.9)$ \\
\hline NA & \\
\hline Mother ( $\mathrm{n}=119)$ & $80(67.2)$ \\
\hline Primary/Secondary & $33(27.7)$ \\
\hline Diploma/degree-holders & $6(5.1)$ \\
\hline NA & $78(65.5)$ \\
\hline
\end{tabular}

NA - not available; SD - standard deviation tant to review inhalation technique in all appointments. Kamps et al showed that repetition of instructions was significantly associated with a more correct inhalation technique irrespective of the type of inhaler used. ${ }^{8}$ These results seem to indicate that previous inhalation teaching may be forgotten, and that it should be provided continually to accomplish and maintain a correct inhalation technique in asthmatic children. Constant information presented at every visit, is vital for the success in asthma management. $^{5}$

We expected to find parental concerns about inhaled therapy, but such a high percentage (68\%) was not expected. A substantial number $(n=28)$ of parents believe that their children can become addicted or dependent to inhaler use. This fear was also referred in similar studies.7,9 In our sample there is a higher proportion of parents with concerns in the group with partially/ uncontrolled asthma, although it was not statistically significant. Furthermore, there are studies that show differences between these groups. A study carried out in Saudi Arabia found that the prevalence of uncontrolled asthma was substantially higher among children of caregivers who agree that it is not good for children to use an inhaler for too long and that inhalers can affect or damage heart. ${ }^{10}$

Uncontrolled asthma is associated with parental beliefs concerning the use and potential side effects of asthma medication, which emphasizes the need to focus efforts to improve knowledge and positively influence parent's perception with respect to inhaled therapy. ${ }^{11}$

Thirteen parents (11\%) consider pMDI's/DPI's use less effective than the use of nebulizers. This finding reinforces the misconceptions parents do have regarding inhaled therapy. Siroux et al showed that parents feel more confident using nebulizers as they believe these are more effective and less harmful than pMDIs or DPIs. ${ }^{9}$

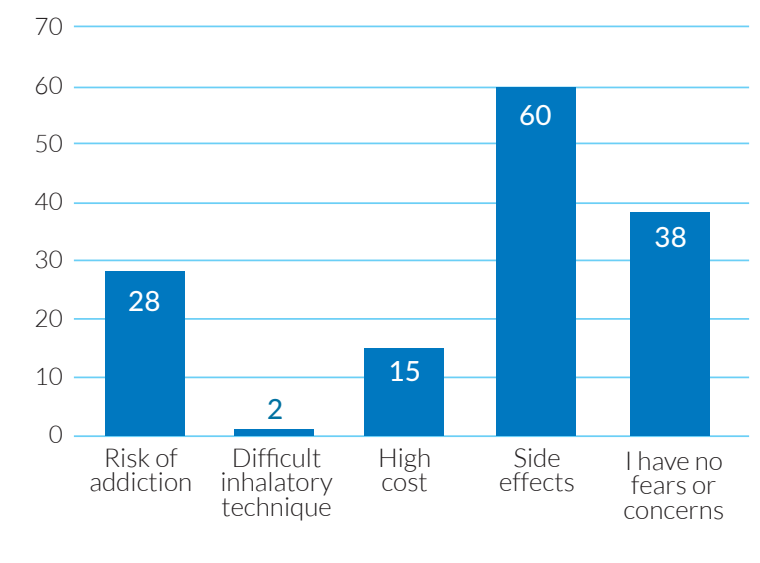

FIGURE 1. Parent's concerns about inhaled asthma therapy. 


\section{QUESTIONNAIRE}

This questionnaire is part of a study undertaken in order to evaluate inhaler treatment in children with asthma or recurrent wheeze. Its purpose is to evaluate parent's perceptions and concerns towards inhaler treatment.

Please be advised that all of your answers will be kept strictly confidential and anonymous. Thank you very much for your cooperation.

\section{To be completed by the PHYSICIAN:}

1. Diagnosis (CA/PCA/UC):

2. Inhaled steroid or inhaled steroid+LABA and device:

3. Inhaled SABA and device:

\section{To be completed by parent's CHILD/ADOLESCENT:}

\section{Data concerning the CHILD/ADOLESCENT:}
4. Age:
5. Sex: Female
Male
6. Any other known illness? No Yes

Data concerning the HOUSEHOLD:

If yes, which one?

7. Parent's age: Father

Mother

8. Parent's educational stage:

Primary education ( $9^{\text {th }}$ grade)

Graduated from high school or equivalent ( $12^{\text {th }}$ grade)

Graduated from college (college degree, master's degree or Ph.D)

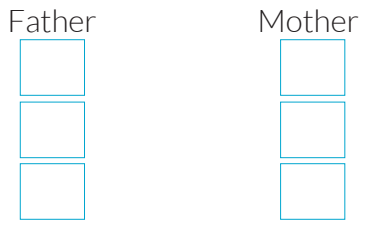

9. Family history of asthma: No $\square$ Yes $\square$

Data concerning INHALED TREATMENT:

10. When did you start inhaled therapy for asthma?

Less than 3 months $\square$ 3-6 months $\square \quad$ 7-12 months $\square$ More than 12 months

11. What frequency do you consider adequate to assess the inhalation technique?

One initial educational session is enough $\square$ Once a year $\square$

12. Do you have any fears or concerns towards inhaled treatment?

Risk of addiction $\square$ Difficult inhalatory technique $\square$ High cost $\square$ Side effects $\square$ I have no fears or concerns

13. Comparing inhaled treatment with aerosol therapy in case of exacerbations, do you consider inhaled treatment:
13.1- More effective
Less effective
Equally effective

13.2- To have a faster onset of action

To have a slower onset of action

To have a similar onset of action

13.3- More side effects $\square \quad$ Less side effects $\square \quad$ Same amount of side effects

14. Are you aware of the reliever treatment in case of breathing difficulty? Yes

If you answer yes, what's the therapy (drug's name and dosage) and how do you use it?

15. What frequency do you consider adequate to assess reliever therapy?

One initial educational session is enough

Once a year

On every consultation 
The majority of patients/parents reported knowing the reliever plan in an exacerbation, although most of them could not explain the plan correctly. Nine patients/parents were unaware of their reliever treatment either because they could not recognize the relief drug or because they did not know its dosage. These results are worrying as they show parents have an inappropriate knowledge of reliever measures.

Compliance with asthma management plans is improved when children and their parents can talk about asthma-related concerns, thoughts and expectations with specialist health professionals. ${ }^{12}$

One of the limitations of our study was the small number of patients with uncontrolled asthma that may have conditioned the results when we compared the different variables with the disease's control.

In conclusion, we found that there are concerns, misconceptions and a lack of parents' knowledge about inhaled therapy. Therefore, we suggest that improvements in education about inhaled therapy should be made, using a variety of approaches such as individual training encouraging the autonomy of the child/adolescent, demonstrations, written action plan, teaching classes or audiovisual material such as mobile applications, to keep a daily record of asthma symptoms, as well as information about medication prescribed. We also consider extremely important the regular review of the inhalation technique and the reliever plan in every consultation.

CONFLICTS OF INTEREST: The authors declare that they have no conflicts of interest.

FINANCIAL SUPPORT: This work has not received any contribution, grant or scholarship.

CONFIDENTIALITY OF DATA: The authors declare that they have followed the protocols of their work center on the publication of data from patients.

PROTECTION OF HUMAN AND ANIMAL SUBJECTS: The authors declare that the procedures followed were in accordance with the regulations of the relevant clinical research ethics committee and with those of the Code of Ethics of the World Medical Association (Declaration of Helsinki).

CONFLITOS DE INTERESSE: Os autores declaram não ter qualquer conflito de interesse na realização do presente trabalho.

FONTES DE FINANCIAMENTO: Não houve qualquer fonte de financiamento na realização do presente trabalho.
CONFIDENCIALIDADE DOS DADOS: Os autores declaram ter seguido os protocolos da sua instituição acerca da publicação dos dados de doentes.

PROTEÇÃO DE PESSOAS E ANIMAIS: Os autores declaram que os procedimentos seguidos na elaboração do presente trabalho estão em conformidade com as normas das comissões de investigação clínica e de ética, bem como da declaração de Helsínquia e da Associação Médica Mundial.

\section{REFERENCES}

1. Masoli M, Fabian D, Holt S, Beasley R; Global Initiative for Asthma (GINA) Program. The global burden of asthma: executive summary of the GINA Dissemination Committee report. Allergy. 2004;59:469-78.

2. Hasegawa K, Tsugawa Y, Brown DF, Camargo CA Jr. Childhood asthma hospitalizations in the United States, 20002009. J Pediatr. 2013; 163:1127-33.e3. doi: 10.1016/j. jpeds.2013.05.002. Epub 2013 Jun 12.

3. Naja AS, Permaul P, Phipatanakul W. Taming Asthma in School-Aged Children: A Comprehensive Review. J Allergy Clin Immunol Pract. 2018;6:726-35. doi: 10.1016/j.jaip.2018.01.023.

4. Rosado Pinto J. ISAAC - 20 anos em Portugal. Acta Pediatr Port. 2011;42:S35-S40.

5. Brand PL. Key issues in inhalation therapy in children. Curr Med Res Opin. 2005;21 Suppl 4:S27-32.

6. Global Initiative for Asthma - Global Strategy for Asthma Management and Prevention. [Accessed June 15, 2018] Available from: http://www.ginasthma.org.

7. Chan PW, DeBruyne JA. Parental concern towards the use of inhaled therapy in children with chronic asthma. Pediatr Int. 2000;42:547-51.

8. Kamps A, van Ewijk B, Roorda R, Brand P. Poor inhalation. technique, even after inhalation instructions, in children with asthma. Pediatr Pulmonol. 2000;29:39-42.

9. Siroux V, Boudier A, Bousquet J, Bresson JL, Cracowski JL, Ferran J, et al. Phenotypic determinants of uncontrolled asthma. J Allergy Clin Immunol. 2009: 124: 681-7 e3. doi: 10.1016/j. jaci.2009.06.010.

10. BinSaeed AA Caregiver knowledge and its relationship to asthma control among children in Saudi Arabia. J Asthma. 2014:51:870-5. doi: 10.3109/02770903.2014.906608. Epub 2014 Apr 7.

11. Koster ES, Wijga AH, Koppelman GH, et al. Uncontrolled asthma at age 8: the importance of parental perception towards medication. Pediatr Allergy Immunol. 2011;22:462-8. doi: 10.1111/j.1399-3038.2011.01150.x. Epub 2011 Feb 20.

12. Miles C, Arden-Close E, Thomas M, Bruton A, Yardley L, Hankins $M$, et al. Barriers and facilitators of effective self-management in asthma: systematic review and thematic synthesis of patient and healthcare professional views. NPJ Prim Care Respir Med. 2017;27:57. doi: 10.1038/s41533-017-0056-4. 